\title{
持久性トレーニングによる心機能変化 〜陸上と水中運動の違い〜
}

\author{
平 澤愛 \\ (杏林大学保健学部)
}

持久性トレーニングは心筋コンプライアンスの増加 を促し, 左心室拡張容積の増大に伴う心拍出量増加と いった，心臟リモデリングが生じることが知られている。 12 ケ月間のマラソントレーニングによる心臓リモデリ ングを検討した研究では, 12 ヶ月後には左心室拡張容 積, 左室壁厚, 左室重量および 1 回拍出量の増加が認め られた（Arbab-Zadeh et al., 2014）。また，心臟の形態 的な変化たけなく，左室収縮機能掞よび拡張機能の一部 にも変化が生じることが報告されている（Weiner et al., 2015).

心機能の評価には, 磁気共鳴画像法 (MRI) や超音波 法が多く用いられている.MRIでは画像分解能が高い一 方, 時間分解能がそしく運動中の測定には適さない。一 方, 超音波法では時間分解能が高く, 運動中の測定も可 能であるが，超音波の入射角度に測定值が大きく影響を 受けることから測定技術が求められる。 また，二次元超 音波法では，心臓の動きを平面的に評価するため，信頼 性と正確性が低いことが問題となっている。しかしなが ら，近年，超音波法のメリットを活かしながら心臟の動 きを三次元的に評価することができる，三次元心臟超音 波診断装置（3Dエコー）が普及してきた。そこでは，三 次元でのスペクトラム・トラッキング法を用いた心筋の 収縮・拡張動態（ストレイン）を詳細に評価することが 可能となった。その中でも，左心室の捻転運動である収 縮期の「ねじれ」(ツイスト) と拡張期の「ほどけ」（ア ンツイスト）は, 収縮機能と拡張機能に大きく影響する。 我々の $3 \mathrm{D}$ エコーを用いた研究では，陸上長距離アス リートの安静時心機能は, 非アスリートと比較して, 左 心室拡張㧍よび収縮容積は有意に大きく, 1 回拍出量が 高い一方で，心筋ストレイン拈よびッイストなど幾つか の心機能の指標はむしろ低下していることが示された。 さらに，健常者では失神を引き起こすような過度の前負 荷減少時には, 心拍出量を維持するための代償機能とし て, 心筋のアンツイスト機能の増大が見られるが，持久 性アスリートでは, この代償機能が低下していた（Hirabuki et al., 2020).この機能低下は, 持久性アスリートに
おける起立耐性低下の要因の一つとして考えられた。

水中では浮力の影響と共に速度の 2 乗に比例して大き くなる水の抵抗を常に受けることから，陸上とは作業環 境が大きく異なる。 また, 水圧により静脈還流量が上昇 することから，運動中の循環器への影響は異なると考え られている。実際，最近の研究においてスイマーはラン ナーと比較して, 安静時の左心室収縮機能に違いは見ら れないが，アンツイスト機能が低いことが報告されてい る(Currie et al., 2018).このことは水中での持久性トレー ニングに特異的な心臓リモデリングが生じている可能性 があり, トレーニング環境の違いにより心臟の適応も特 異的に変化することを示唆する。

本発表では持久性トレーニングが心臓リモデリングに 及ぼす影響に関して, 我々の研究成果を含む最新の知見 を紹介し，陸上運動と水中運動の違いについて生理学的 視点から議論を㧍こなった。

\section{参考文献}

Arbab-Zadeh A, Perhonen M, Howden E, Peshock RM, Zhang R, Adams-Huet B, Haykowsky MJ, Levine BD. Cardiac Remodeling in Response to 1 Year of Intensive Endurance Training, Circulation. 2014; $130(24)$ : 2152-61.

Weiner RB, DeLuca JR, Wang F, Lin J, Wasfy MM, Berkstresser B, Stöhr E, Shave R, Lewis GD, Hutter AM Jr, Picard MH, Baggish AL. Exercise-Induced Left Ventricular Remodeling Among Competitive Athletes: A Phasic Phenomenon, Circ Cardiovasc Imaging. 2015; 8(12): e003651.

Hirabuki K, Hata N, Suzuki R, Suda T, Uechi T, Fukuie M, Hirasawa A, Matsuda T, Sugawara J, Shibata S. Underlying Mechanism of Orthostatic Intolerance due to Athlete's Heart An Approach with Three-Dimensional Echocardiography, 25th Annual Congress of the European College of Sports Science, 2020.

Currie KD, Coates AM, Slysz JT, Aubry RL, Whinton AK, Mountjoy ML, Millar PJ, Burr JF. Left Ventricular Structure and Function in Elite Swimmers and Runners, Front Physiol. 2018 Nov 28; 9: 1700. 